\title{
Germination and seedling growth responses of Sri Lankan grown Sesame/Thala (Sesamum indicum L.) for simulated drought conditions
}

\author{
I.A.J.K. Dissanayake ${ }^{{ }^{*}}$, S.M.W. Ranwala ${ }^{1}$ and S.S.N. Perera ${ }^{2}$ \\ ${ }^{\prime}$ Department of Plant Sciences, Faculty of Science, University of Colombo, Colombo 03. \\ ${ }^{2}$ Department of Mathematics, Faculty of Science, University of Colombo, Colombo 03.
}

Submitted: 28 November 2018; Revised: 06 August 2019; Accepted: 28 August 2019

\begin{abstract}
The agriculture sector is often challenged by dry weather, thus a better understanding of growth responses of crops to changes in climate is imperative. However, drought responses of many economical crops are yet to be comprehensively studied. Therefore, this research was carried out to investigate the responses of 10 Sri Lankan grown sesame varieties/cultivars: Uma, Malee, Idal, Pokuru, Black-seeded sesame and its wild relatives, to reduced water availability during germination and seedling growth. Drought conditions were simulated in a laboratory with three different treatments [polyethylene glycol (PEG) 6000, mannitol and sodium chloride] at $0,-0.25,-0.5$ and $-1.0 \mathrm{MPa}$ water potentials under complete randomised design with 10 replicates each having eight seeds per petri plate per variety/cultivar. The final germination percentage of sesame seeds after 10 days was calculated. Seedlings were further exposed to the same treatments and their root and shoot lengths were measured after 10 days. Germination was assessed using binary data analysis and the seedling data were subjected to ANOVA. Results revealed that the highest tension of PEG (-1.00 MPa) inhibited seed germination and the emergence of seedlings, while that of mannitol (-1.00 MPa) negatively affected seedling growth only $(\mathrm{p}<0.001)$. It is concluded that sesame varieties/ cultivars were drought susceptible at a tension of $-1.00 \mathrm{MPa}$ during germination and seedling development. Improved cultivars (Uma and Malee) showed to be more drought tolerant during germination and landraces (Idal and Pokuru) were the least susceptible to drought during seedling growth. Seedlings of Black ${ }_{1}$, Wild 1 , Wild, Pokuru and Uma varieties/cultivars developed morphological adaptations to display drought avoidance responses during the period of drought stress.
\end{abstract}

Keywords: Drought tolerance, germination, gingelly, seedling growth, sesame.

\section{INTRODUCTION}

With climate change, it is expected that drought conditions will increase in frequency and intensity in the coming years, severely affecting agriculture, especially rain-fed agriculture and threaten the food security of humans (IPCC, 2014). Effects of drought on crops are multiple and complex as they interfere with the composition, structure and function of plants from sub-cellular levels to ecosystem level depending on the severity of the drought regime, and the phenological and developmental stages of the crop (De Costa, 2004, 2010; Lambers et al., 2008; Alqudah et al., 2011). Drought responses of major crops such as rice, wheat, barley, sorghum, and maize have already been extensively researched (Harris et al., 2007; Ali et al., 2013; Odabas et al., 2014; He et al., 2016; Ramya et al., 2016) and insights have been made to develop drought-resistant varieties. However, many other economical crops are yet to be comprehensively studied.

Sesame (Sesamum indicum L., Family Pedaliaceae) has been reported to be highly responsive to many environmental factors such as air temperature, salinity, heavy metals and soil moisture (Bor et al., 2009) which

" Corresponding author (jinenkd@yahoo.com; (D https://orcid.org/0000-0002-6449-0745) 
affect its growth (reduction in length of shoots and roots, and biomass) and yield performance. Nevertheless, detailed studies on responses of sesame to environmental conditions are underestimated and reports are limited (Nath et al., 2001; Olowe et al., 2009).

Being the major rain-fed oil seed crop cultivated in Sri Lanka (Weeraratna \& Weerasinghe, 2009), different sesame cultivars are grown in the island. For instance, white seeded sesame cultivars are mainly grown in the South eastern regions while black seeded cultivars are common in the North western parts of the country (Dissanayake et al., 2017). Either white or black seeded sesame cultivars are cultivated in other parts of the country depending on the seed availability. Pokuru and Idal are the white seeded landraces found in cultivations in Sri Lanka. Limited cultivation of improved cultivars, namely, Uma (white seeded) and Malee (brown seeded) are also recorded in Hambantota district.

Despite the high international demand of sesame for oil, bakery and confectionary products, it is identified as an underutilised crop in Sri Lanka (Dissanayake et al., 2017). Nevertheless, the Sri Lankan government has taken initiatives to expand sesame cultivation to reach zero imports by the year 2020 (Department of National Planning, 2010).

This study comparatively assessed the drought resistance of Sri Lankan grown sesame cultivars and its wild relatives through experiments conducted by simulating reduced water availability during seed germination, and seedling growth and establishment. We hypothesised that germination and seedling growth of sesame varieties/cultivars respond differently to water availability of the environment.

Osmotic stress is often simulated using osmotica such as polyethylene glycol (PEG), mannitol, sodium chloride $(\mathrm{NaCl})$, sucrose and glucose in laboratory experiments (Mensah et al., 2009; Boureima et al., 2011; Bahrami et al., 2012). PEG and mannitol are organic compounds not largely ionised in water, but mainly exert osmotic effects compared to $\mathrm{NaCl}$, which is inorganic and ionised in water imposing a salinity effect in addition to the osmotic effect (Mensah et al., 2009). PEG is non-toxic to plant cells and metabolism, hence, considered as a better osmoticum to study drought responses in laboratory experiments (Verslues et al., 2006; Mensah et al., 2009; Bahrami et al., 2012).

Here, simulated drought stress was quantified with regard to the osmotic potential to identify varieties/ cultivars tolerant to drought during germination and seedling growth stages. It was assumed that the use of different osmotica will also reveal hints on how sesame could cope with salinity stress induced by $\mathrm{NaCl}$.

\section{METHODOLOGY}

\section{Plant material}

Seed samples from 10 different sesame varieties/ cultivars were used. These included black seeded cultivars (Black

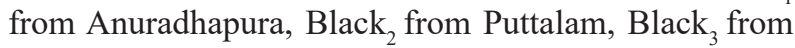
Hambantota), black seeded wild varieties from the Plant Genetic Resources Centre (PGRC), Gannoruwa (Wild $_{1}$ - accession no. 002324 origin from Gampaha, Wild $_{2}$ - accession no. 008824 origin from Matale, Wild - accession no. 001853 origin from Kandy), white seeded Idal (meaning broom) and Pokuru (meaning clusters) landraces from Hambantota, and Uma and Malee developed by the Grain Legumes and Oil Crops Research and Development Centre of the Department of Agriculture (DOA), Angunakolapelessa, Sri Lanka.

\section{Germination and seedling growth experiment}

Drought stress on the germination of sesame seeds was simulated at $29{ }^{\circ} \mathrm{C}$ and $12 \mathrm{~h}$ day/night conditions under complete randomised design with 10 replicates each having 8 seeds per petri plate per variety/cultivar. Treatments included osmotica: PEG 6000, mannitol and $\mathrm{NaCl}$ at $-0.25,-0.5$ and $-1.0 \mathrm{MPa}$ osmotic potentials selected upon results of a trial experiment conducted to simulate drought stress at water potential levels equivalent to $-0.25,-0.5$ and $-1.0 \mathrm{MPa}$, respectively. Distilled water $(0 \mathrm{MPa})$ was used as the control.

Having known the solute concentration, osmotic (solute) and water potentials exerted by a given solution can be expressed by the Van' Hoff equation (equation 1) (Ashraf \& Abu-Shakra, 1978; Richards, 2005) and summing up of its components (equation 2) (Sanders \& Arndt, 2012).

Osmotic potential $\left(\psi_{s}\right)=-i C R T$

where $i=$ number of particles the molecule makes in water, $C=$ molar concentration $(\mathrm{mol} / \mathrm{L}), R=$ pressure constant $(0.0821 \mathrm{~L}$ atm $/ \mathrm{mol} / \mathrm{K})$, and $T=$ temperature in $\mathrm{K}$

Water potential $\left(\psi_{w}\right)+$ pressure potential $\left(\psi_{p}\right)$

$$
=\operatorname{osmotic} \text { potential }\left(\psi_{s}\right)
$$


Thus, a range of water potential values and subsequent drought stress conditions could be imposed by a concentration gradient of an osmoticum.

Sesame seeds washed under running tap water for 20 min were placed on a Whatman filter paper soaked in $10 \mathrm{~mL}$ of treatment solution in petri plates $(100 \mathrm{~mm}$ * $15 \mathrm{~mm}$ ). Seeds were considered as germinated when the radical was approximately $5 \mathrm{~mm}$ long. Observations were recorded every $48 \mathrm{~h}$ within a 10 -day period and the germinability (germination percentage) was calculated (McNair et al., 2012).

Binary data analysis detected differences in germination at different drought stress (water potential) levels. Number of seeds germinated was converted to an odds value, i.e. the probability of germination for a treatment $(P) /$ probability that germination did not occur for the same treatment (1-P) (Thattil et al., 1999) and the effects were compared using the ratios, i.e. the ratio of the probabilities for germination for any two treatments being compared. When the odds ratio was significantly different from 1 , the compared treatments were considered to differ significantly from each other (James et al., 2003). Odds ratio for any treatment was compared against the response of the seeds in the control at full water availability $(0 \mathrm{MPa})$, i.e. numerator was the odds in the treatment and denominator was the odds in the control. In order to test for interaction effects, the data were stratified by variety and post-hoc comparisons were done based on odds.

All germinated seeds of the 10 varieties/cultivars were separately transferred into a tray containing sterile sand, saturated with the respective treatment solutions for further growth. Root and shoot lengths of 10 developing seedlings of each variety/cultivar were measured after 10 days. Each seedling represented a replicate. The data were subjected to analysis of variance (ANOVA) to detect differences among drought stress (water potential) levels.

Data were analysed using Statistical Analysis System (SAS) software version 9.3 (SAS Institute, Cary, North Carolina, U.S.) and GraphPad Prism 6 (GraphPad Software, Inc., CA) was used for generating graphs. Logistic regression was followed with PROC LOGISTIC procedure to study the effect of osmotic treatments on germination response of seeds of 10 sesame varieties. Firth's penalised likelihood method was used to alleviate issues with quasi separation. During ANOVA, the mean separation of the parameters with significant differences was done by Duncan's multiple range test. Normal distribution was evaluated using the Shapiro-Wilk W test and the data were transformed (to square root of root and shoot lengths) to meet the assumptions of ANOVA.

\section{Drought tolerance}

Drought tolerance of the tested varieties/cultivars was evaluated against tolerance indices, namely, reduction rates of germination and growth of seedlings following the formula (equation 3) given by Boureima et al. (2011).

Reduction rate $(\%)=\left[1-\frac{V_{s}}{V_{p}}\right] * 100$

where $V_{s}$ and $V_{p}$ are the mean of the parameter under stressed and non-stressed conditions, respectively.

\section{RESULTS AND DISCUSSION}

\section{Seed germination}

A test of the full model against a constant-only model was statistically significant, indicating that the treatments and varieties reliably distinguished between germination responses $\left(\mathrm{X}^{2}=5986, \mathrm{p}<0.001\right.$ with $\left.d f=99\right)$ with a $93 \%$ concordant value. Wald criterion demonstrated that the effect of treatment, varietal/cultivar difference and treatment variety/cultivar interactions were significant $(\mathrm{p}<0.001)$.

Osmotic treatments had a significant effect $(\mathrm{p}<0.001)$ on all sesame varieties/cultivars.

Black seeds (Black $)_{1}$ ) showed a significant decrease in germination percentage with increased osmotic tension of PEG and mannitol (Figure 1a). Black ${ }_{2}$ seeds did not germinate to any appreciable degree under any treatment

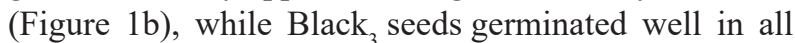
treatments except for PEG at $-1.00 \mathrm{MPa}$ (Figure 1c). Wild sesame seeds, especially Wild and Wild ${ }_{2}$, showed negative germination responses to osmotica, PEG and mannitol (Figure 1d, 1e, and 1f). Landraces Idal and Pokuru responded positively to mannitol and PEG (except for -1.00 MPa of PEG) and negatively to high tension of osmotic stress imposed by $\mathrm{NaCl}$ (Figure $1 \mathrm{~g}$ and 1h). Seeds of Uma and Malee cultivars germinated well regardless of the treatment and were only affected at the highest tension of osmotic stress imposed by PEG (-1.00 MPa) (Figure 1i and $1 \mathrm{j})$.

In general, Wild and Idal seeds showed lower germination percentages (less than $70 \%$ ) even in distilled water (Figure 1d, 1e, 1f and 1g,). The low values of germination exposed to distilled water may 


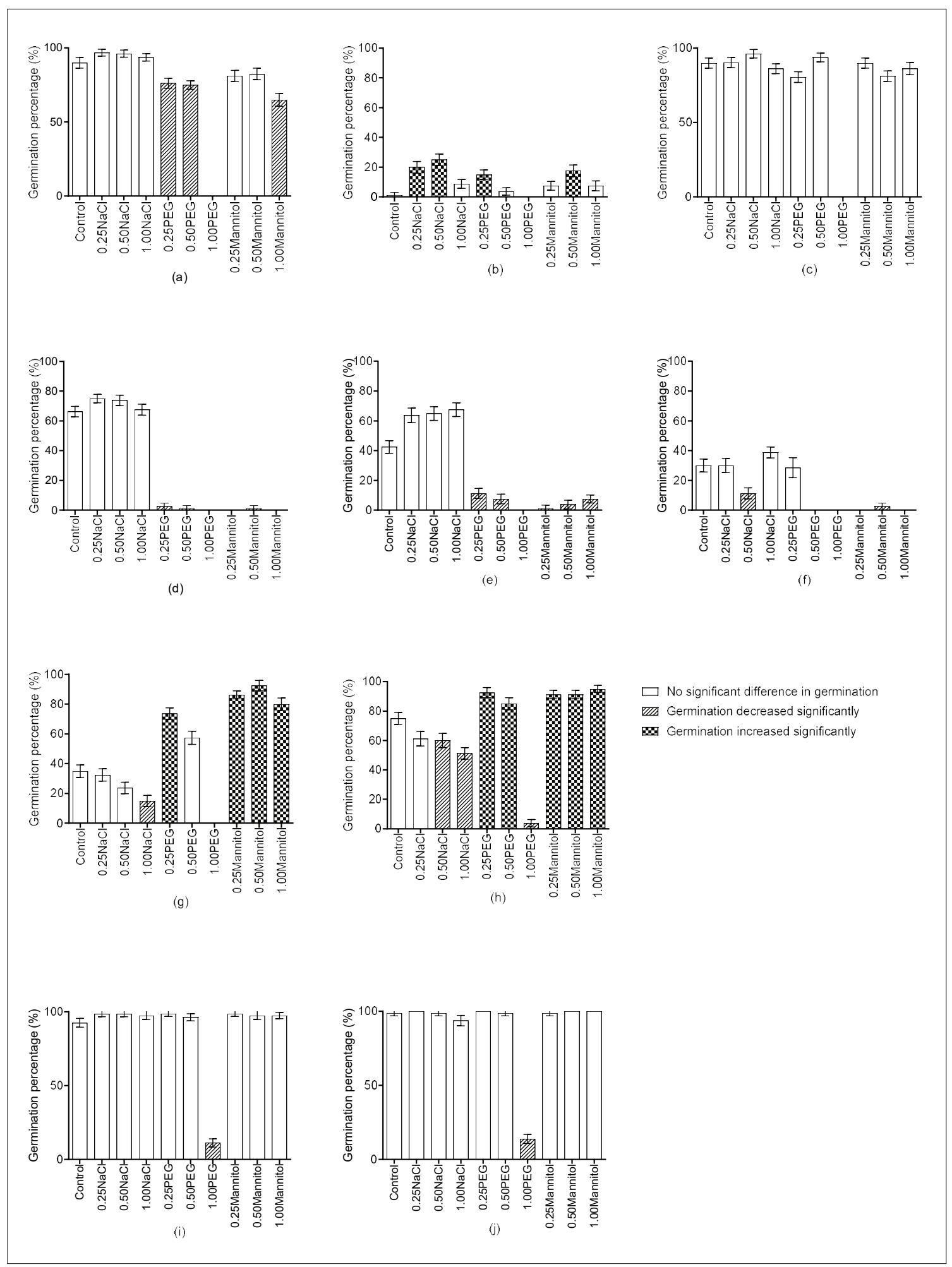

Figure 1: Effect of simulated water stress on germination percentage of sesame cultivars: Black $(a), B_{1} \operatorname{Black}_{2}(\mathrm{~b}), \mathrm{Black}_{3}(\mathrm{c})$, Wild $_{1}(\mathrm{~d})$, Wild $_{2}$ (e), Wild (f), Idal (g), Pokuru (h), Uma (i) and Malee (j). Data are the mean germination percentages + standard error and the values with the same colour are not statistically different from the control at $\mathrm{p}=0.05$ level (based on odds ratios). 
reflect the germination capacity of the seeds of Wild and Idal that were randomly selected from PGRC and a composite sample of seeds obtained from the farmers in Hambantota, respectively. Germination of seeds of the varieties/cultivars, except for Uma and Malee, was completely inhibited by a water potential of $-1.00 \mathrm{MPa}$ of PEG. At the end of 10-day period, germinated Uma, Malee and Pokuru seeds also did not complete shoot emergence at $-1.00 \mathrm{MPa}$ water potential imposed by PEG. Nevertheless, the radical continued to grow increasing the length of the roots.

\section{Seedling establishment and growth}

A two-way analysis of variance of square root of root length of seedlings exhibited a significant interaction between simulated osmotic treatments and variety/ cultivar $[\mathrm{F}(60,1053)=3.29, \mathrm{p}<0.001]$. Both effects of osmotic treatments $[\mathrm{F}(60,1053)=76.04, \mathrm{p}<0.001]$ and variety/cultivar differences $[\mathrm{F}(60,1053)=24.19$, $\mathrm{p}<0.001]$ were significant. Thus, the effect of osmotic stress on seedling growth depended on the variety/ cultivar. The means for the osmotic treatments were significantly different for Black $_{1}[\mathrm{~F}(60,1053)=21.30$, $\mathrm{p}<0.05]$, Black $_{2}[\mathrm{~F}(60,1053)=3.38, \mathrm{p}>0.05]$, Black $_{3}$ $[\mathrm{F}(60,1053)=11.54, \mathrm{p}>0.05]$, Wild $[\mathrm{F}(60,1053)=$ 2.07, $\mathrm{p}<0.05]$, Wild $[\mathrm{F}(60,1053)=10.86, \mathrm{p}<0.05]$, Wild $_{3}[\mathrm{~F}(60,1053)=3.23, \mathrm{p}<0.05]$, Idal $[\mathrm{F}(60,1053)=$ $17.46, \mathrm{p}<0.05]$, Pokuru $[\mathrm{F}(60,1053)=9.51, \mathrm{p}<0.05]$, Uma $[\mathrm{F}(60,1053)=18.84, \mathrm{p}<0.05]$ and Malee $[\mathrm{F}(60$, $1053)=9.73, p<0.05]$. The effects of different levels of osmotic stress (as indicated by the water potential) on root growth recorded 10 days after planting exhibited a significant reduction of sesame root growth with increased osmotic tension of mannitol (Figure 2a, 2b, 2c, $2 \mathrm{e}, 2 \mathrm{~g}, 2 \mathrm{~h}, 2 \mathrm{i}$, and $2 \mathrm{j}$ ).

The wild varieties hardly survived in the mannitol solutions (Figure 2d and 2f). Increasing the osmotic tension of $\mathrm{NaCl}$ also reduced root elongation in Black , Wild $_{1}$ and Uma sesame seedlings (Figure 2c, 2d, and 2i). In contrast, increasing tension of PEG induced root growth of Black, Wild Wild $_{2}$, Pokuru and Uma seedlings compared to that of the control (Figure 2a, 2d, 2e, 2h, and 2i).

Two-way analysis of variance of square root of shoot length of seedlings indicated a significant interaction between simulated osmotic treatment and variety/ cultivar $[\mathrm{F}(60,1053)=10.08, \mathrm{p}<0.001]$. Both effects of osmotic treatment $[\mathrm{F}(60,1053)=108.54, \mathrm{p}<0.001]$ and variety/cultivar $[\mathrm{F}(60,1053)=113.70, \mathrm{p}<0.001]$ were significant. The means for the osmotic treatments were significantly different for Black ${ }_{1}[\mathrm{~F}(60,1053)=35.83$, $\mathrm{p}<0.05]$, Black $_{2}[\mathrm{~F}(60,1053)=4.03, \mathrm{p}>0.05]$, Black $_{3}$ $[\mathrm{F}(60,1053)=16.32, \mathrm{p}>0.05]$, Wild $_{1}[\mathrm{~F}(60,1053)=3.08$, $\mathrm{p}<0.05]$, Wild $_{2}[\mathrm{~F}(60,1053)=6.23, \mathrm{p}<0.05]$, Wild $_{3}$ $[\mathrm{F}(60,1053)=4.83, \mathrm{p}<0.05]$, Idal $[\mathrm{F}(60,11053)=27.48$, $\mathrm{p}<0.05]$, Pokuru $[\mathrm{F}(60,1053)=31.05, \mathrm{p}<0.05]$, Uma $[\mathrm{F}(60,1053)=35.93, \mathrm{p}<0.05]$, and Malee $[\mathrm{F}(60,1053)=$ $25.73, \mathrm{p}<0.05]$.

Growth performance of the shoots in response to osmotic solutions recorded 10 days after planting indicated a low growth increment in white, black and brown seeded sesame varieties/cultivars treated with high osmotic tension provided by mannitol (Figure 3a, $3 \mathrm{~b}, 3 \mathrm{c}, 3 \mathrm{e}, 3 \mathrm{~g}, 3 \mathrm{~h}, 3 \mathrm{i}$, and $3 \mathrm{j}$ ).

Wild seedlings did not survive in mannitol (Figure $3 \mathrm{~d}$ and $3 \mathrm{f}$ ). Lower osmotic tensions of $\mathrm{NaCl}$, induced shoot growth in Black , Black $_{3}$, Wild 2 , Pokuru, Uma, and Malee (Figure 3a, 3c, 3e, 3h, 3i, and 3j). Seeds of Black did not germinate in distilled water (Figure 1b) possibly due to the germination capacity of the seeds, which were also randomly selected from a composite seed sample and hence, no further measurements were taken.

\section{Drought tolerance}

Among the treatment regimes, the highest tension of PEG (-1.00 $\mathrm{MPa})$ significantly lowered germination of sesame seeds (Figure 1) and the highest tension of $(-1.00 \mathrm{MPa})$ mannitol negatively affected the growth of sesame seedlings (Figures 2 and 3). Reduction rates of germination and seedling growth calculated for -1.00 MPa PEG and -1.00 MPa mannitol, respectively (Table 1) indicated that seed germination of wild (Wild ${ }_{1}$, Wild $_{2}$, Wild $)_{3}$, black $\left(\right.$ Black $_{1}$, Black $_{2}$, Black $_{3}$ ) and Idal sesame was completely (100\%) reduced by $-1.00 \mathrm{MPa}$ PEG, whereas Uma and Malee showed a relatively low germination reduction ( $88 \%$ and $86 \%$, respectively), suggesting high tolerance of Uma and Malee compared to the other tested varieties/cultivars.

Water potential directly indicates the availability of water for the survival of living cells. In most instances in a tropical climate, at field capacity where soil water is abundant, $\psi_{w}$ remains as $-0.033 \mathrm{MPa}$, providing a favourable condition for optimum crop growth. When $\psi_{w}$ hits the permanent wilting point generally considered to be $-1.5 \mathrm{MPa}$, the crops are severely stressed and irreversibly damaged (Elkheir et al., 2016).

Our results showed that none of the seedlings of Wild $_{1}$ and Wild $_{3}$ sesame survived in -1.00 MPa imposed by mannitol indicating that they were highly susceptible 


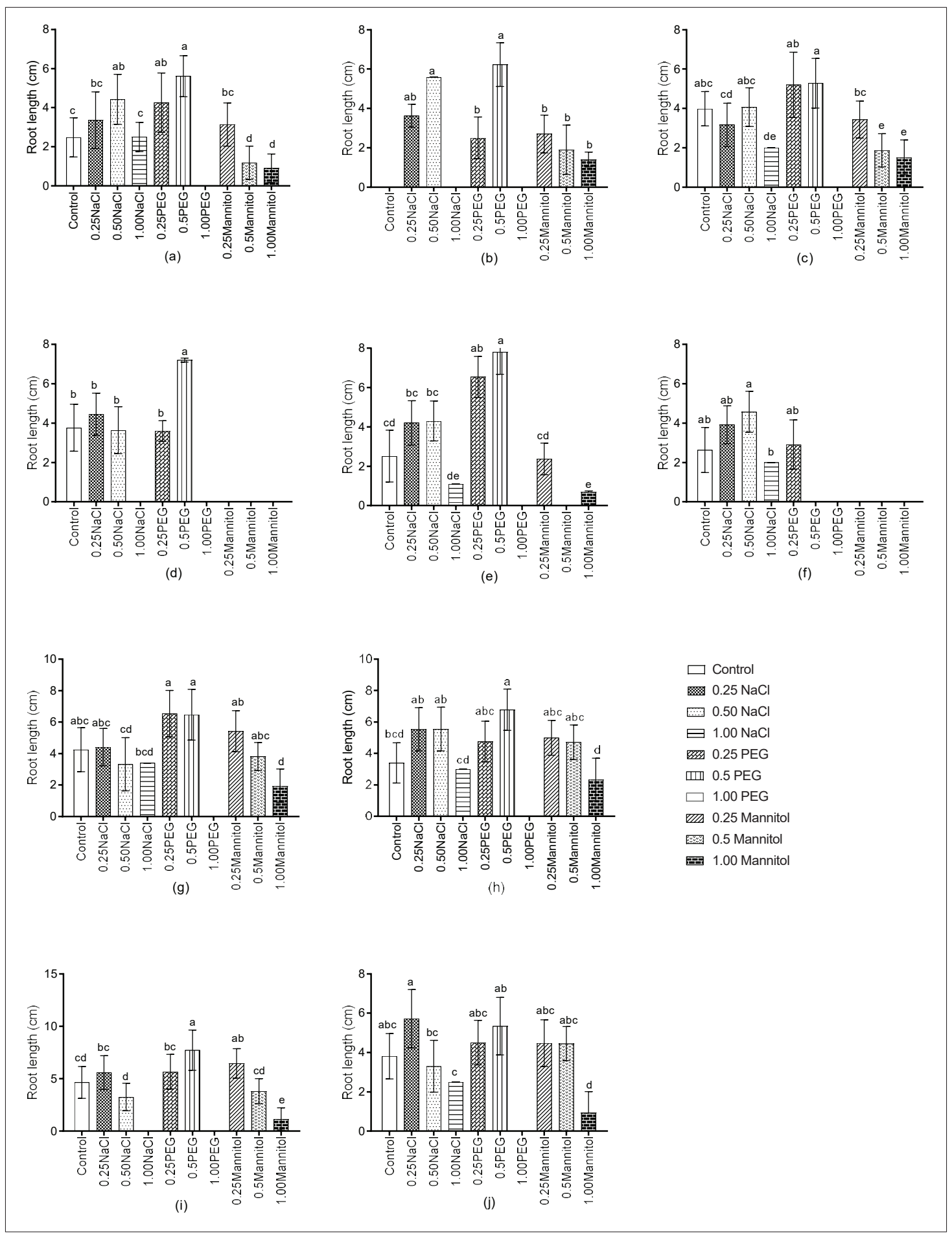

Figure 2: Effects of different osmotic treatments on root growth of sesame seedlings: Black ${ }_{1}(\mathrm{a})$, Black $_{2}(\mathrm{~b})$, Black $_{3}(\mathrm{c})$, Wild $_{1}$ (d), Wild ${ }_{2}$ (e), Wild ${ }_{3}$ (f), Idal (g), Pokuru (h), Uma (i) and Malee (j). Data represent the mean and standard error of 10 replicates. Bars that share a common letter are not significantly different by Duncan's multiple range test at $95 \%$ confidence interval. 
to drought during seedling growth. It was not possible to calculate the reduction rate for Black ${ }_{2}$, as none of the seedlings survived in the control. Seedlings of landraces Pokuru (40\%) and Idal (58\%) were shown to be the most tolerant to root growth although moderate reductions in shoot growth (62 and $60 \%$, respectively) were observed. Shoot growth of Black seeded varieties $\left(\right.$ Black $_{1}-48 \%$ and Black $\left._{3}-44 \%\right)$ and Uma (44\%) were least affected by mannitol. Wild ${ }_{2}$, Black $_{1}$, Black $_{3}, U m a$ and Malee plants were moderately drought tolerant to root growth
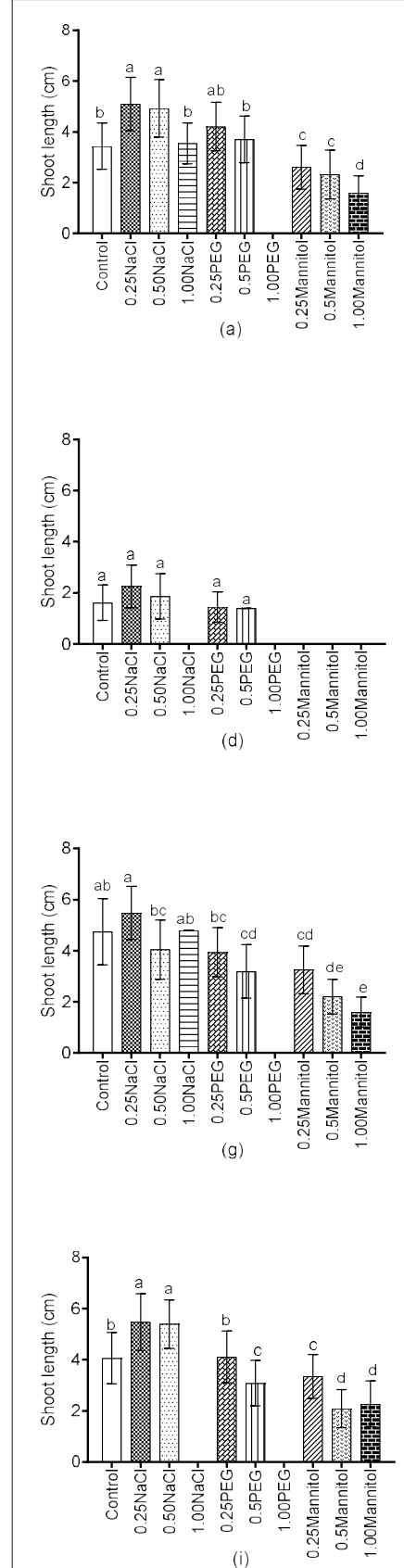

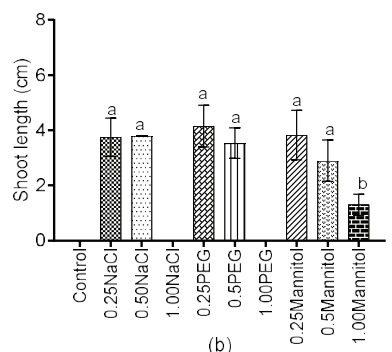

(b)
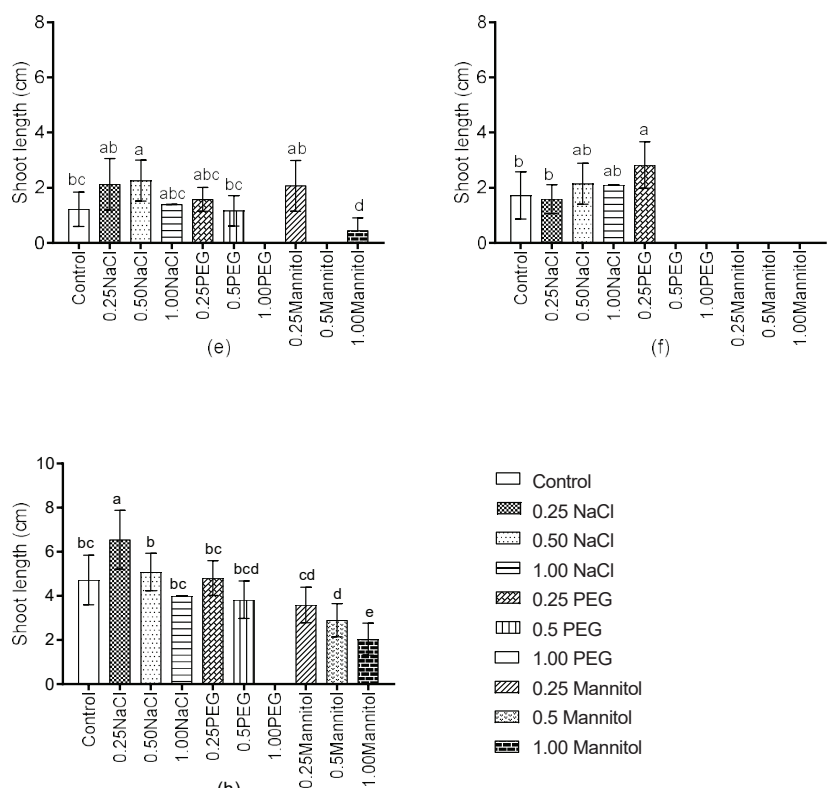

$$
\begin{aligned}
& \square \text { Control } \\
& 0.25 \mathrm{NaCl} \\
& 0.50 \mathrm{NaCl} \\
& \square 1.00 \mathrm{NaCl} \\
& 0.25 \mathrm{PEG} \\
& \square 1.00 \mathrm{PEG} \\
& \square 0.25 \text { Mannitol } \\
& 0.5 \text { Mannitol } \\
& 1.00 \text { Mannitol }
\end{aligned}
$$

Figure 3: Effects of different osmotic treatments on shoot growth of sesame seedlings: Black ${ }_{1}(\mathrm{a}), \mathrm{Black}_{2}$ (b), Black (c), Wild $($ d), Wild (e), Wild (f), Idal (g), Pokuru (h), Uma (i) and Malee (j). Data represent the mean and standard error of 10 replicates. Bars that share a common letter are not significantly different by Duncan's multiple range test at $95 \%$ confidence interval. 
(72, 64, 64, 78 and $77 \%$, respectively).

Similarly, the reduction of germination of all varieties/ cultivars by $-1.00 \mathrm{MPa}$ imposed by PEG can be attributed to limited or no water uptake during germination under decreased water potential conditions, thus no seeds completed seedling emergence.

Regardless of the source of water potential, results of the germination and seedling growth experiments showed that sesame varieties/cultivars were drought susceptible at an osmotic tension of -1.00 MPa during germination and seedling growth. Uma and Malee were shown to be the most drought tolerant cultivars at the germination stage. They also showed moderate drought tolerance during seedling growth. Idal and Pokuru were moderately drought tolerant during germination and highly tolerant during seedling growth. Wild sesame plants were highly sensitive and intolerant to water deficit conditions at times of germination and seedling growth.

Biomass partitioning of roots and shoot growth provides a functional balance of growth. Shoot growth depends on the water absorbed from the root, whereas root growth depends on the supply of photosynthates from the shoot. At times of drought stress when shoot expansion becomes limited, accumulated photosynthates are translocated to the root allowing it to expand for search of soil water. Plants that increase root depth, root to shoot ratio and maintain water potential above that of the environment are termed as 'Water Spenders' (Bodner et al., 2015) and it is a morphological adaptation that plants develop to avoid drought stress by optimizing water uptake (Farooq et al., 2009, 2012). Seedlings of Black $_{1}$, Wild, Wild $_{2}$, Pokuru and Uma were capable of developing deep root systems under drought stress
(Figure 2a, 2d, 2e, 2h, 2i and Table 2) in favour of maximising its water absorption capacity to overcome drought stress at the seedling stage.

The order of effects produced by different osmotica on germination was PEG $>$ mannitol $>\mathrm{NaCl}$ where no seedlings emerged at $-1.00 \mathrm{MPa}$ PEG treatment. The order of effects on seedling growth was mannitol $>\mathrm{PEG}>\mathrm{NaCl}$, hence, $\mathrm{PEG}$ and mannitol had high osmotic influence compared to that of $\mathrm{NaCl}$. This observation is in agreement with the claim made by Luan et al. (2014) that, compared to $\mathrm{PEG}, \mathrm{NaCl}$ had a less inhibitory influence on the germination of sunflower seeds, another oilseed crop. However, findings of a similar experiment carried out by Mensah et al. (2009) in Nigeria showed an order

Table 1: Comparison of reductions in germination and root and shoot length of sesame.

\begin{tabular}{lccc}
\hline & RPG (\%) & RPSR (\%) & RPSS (\%) \\
\hline Black $_{1}$ & 100 & 64 & 48 \\
Black $_{2}$ & 100 & $N S^{a}$ & $N S^{a}$ \\
Black $_{3}$ & 100 & 64 & 44 \\
Wild $_{1}$ & 100 & 100 & 100 \\
Wild $_{2}$ & 100 & 72 & 60 \\
Wild $_{3}$ & 100 & 100 & 100 \\
Idal $_{\text {Pokuru }}$ & 100 & 58 & 62 \\
Uma & 95 & 40 & 60 \\
Malee & 88 & 77 & 44 \\
\hline
\end{tabular}

${ }^{a} N S$ - seedlings did not survive to calculate reduction percentage. RPG - reduction rate of germination; RPSR - reduction percentage of seedling root length; RPSS - reduction percentage of seedling shoot.

Table 2: Effects of different osmotic solutions on shoot:root of the seedlings

\begin{tabular}{lccccccccc}
\hline & Control & \multicolumn{3}{c}{$\mathrm{NaCl}(\mathrm{MPa})$} & \multicolumn{3}{c}{ PEG (MPa) } & \multicolumn{3}{c}{ Mannitol (MPa) } \\
& $0(\mathrm{MPa})$ & -0.25 & -0.5 & -1.0 & -0.25 & -0.5 & -0.25 & -0.5 & -1.0 \\
\hline & & & & & & & & & \\
Black $_{1}$ & 1.39 & 1.52 & 1.11 & 1.42 & 0.99 & 0.66 & 0.83 & 1.97 & 1.80 \\
Black $_{2}$ & - & 1.03 & 0.68 & - & 1.66 & 0.57 & 1.42 & 1.53 & 0.93 \\
Black $_{3}$ & 0.73 & 1.27 & 1.21 & 1.65 & 0.73 & 0.67 & 0.81 & 1.47 & 1.04 \\
Wild $_{1}$ & 0.43 & 0.51 & 0.51 & - & 0.40 & 0.17 & - & - & - \\
Wild $_{2}$ & 0.49 & 0.51 & 0.53 & 1.27 & 0.24 & 0.15 & 0.87 & - & 0.64 \\
Wild $_{3}$ & 0.65 & 0.40 & 0.47 & 1.05 & 0.97 & - & - & - & - \\
Idal $_{\text {Pokuru }}$ & 1.12 & 1.24 & 1.22 & 1.41 & 0.61 & 0.49 & 0.60 & 0.58 & 0.82 \\
Uma $_{\text {Malee }}$ & 1.39 & 1.18 & 0.92 & 1.33 & 1.01 & 0.57 & 0.72 & 0.62 & 0.87 \\
& 0.87 & 0.98 & 1.66 & - & 0.72 & 0.40 & 0.52 & 0.55 & 1.97 \\
& 1.04 & 0.91 & 1.31 & 0.88 & 0.91 & 0.60 & 0.62 & 0.58 & 1.64 \\
\hline
\end{tabular}


of potency of $\mathrm{NaCl}>$ Glucose $>$ PEG on sesame seed germination, which can be attributed to the susceptibility to salinity rather than drought susceptibility. Although $\mathrm{NaCl}$ was imposing salinity stress in the present study, germination of sesame seeds would have been more vulnerable to osmotic/drought stress than salinity stress. Similarly, observations on Idal and Pokuru cultivars indicated their vulnerability to salinity stress during germination. Black ${ }_{3}$ and Wild ${ }_{1}$ also showed signs of vulnerability to salinity stress during seedling growth as imposed by $\mathrm{NaCl}$ at $-1.00 \mathrm{MPa}$. Induced seed germination and shoot growth with lower osmotic potentials of $\mathrm{NaCl}$ could possibly be due to its $\mathrm{Na}^{+}$and $\mathrm{Cl}^{-}$ions that can mobilise through cell membranes which could, in turn, lower cellular water potential and increase water uptake (Luan et al., 2014). Conversely, these authors have also declared that higher osmotic potential of $\mathrm{NaCl}$ can cause a toxic effect on germination and seedling growth. Mensah et al. (2009) also provided evidence that seed germination and seedling growth of sesame are negatively affected by $\mathrm{NaCl}$ at an osmotic potential of $-0.5 \mathrm{MPa}$. A previous study conducted by Ramírez et al. (2007) on sesame demonstrated that there is a profound difference in germination percentages of various sesame genotypes in response to increased salinity stress.

Although it was presumed that PEG and mannitol would affect germination and seedling growth in the same way, in this study, mannitol showed only positive or neutral effects on sesame seed germination while PEG negatively influenced seed germination. Conversely, mannitol negatively affected seedling (both root and shoot) growth whereas PEG induced root growth of sesame seedlings. While working on wheat, Almansouri et al. (2001) also showed that mannitol had no effect on seed germination but negative significant effects on seedling length. Similar to $\mathrm{NaCl}$, mannitol is a penetrating solute that decreases internal cellular water potential and facilitates osmotic water uptake inducing germination. Therefore, mannitol does not impose any inhibitory effect on seed germination. However, reduced seedling growth at the higher osmotic potential of mannitol is unexpected unless it is hypothesised that mannitol induces mild toxic effects at higher concentrations as shown by $\mathrm{NaCl}$ in the study conducted by Luan et al., (2014). Mannitol is a form of reduced sugar mannose that is generally distributed in plant cells. In response to drought and salinity stress, it is evident that mannitol is accumulated in plant cells to act as osmoprotectant and antioxidant (Patel \& Williamson, 2016). Hence, there should be another mechanism which explains the reducing effect of mannitol on sesame seedlings. By working on cucumber and pea seedlings, Stahlberg and Cosgrove (1997) demonstrated that mannitol had negative effects on the growth of cucumber seedlings whereas no effect was recorded on pea seedlings. Further, these authors confirmed that mannitol was not penetrating into root cells of the seedlings and the reduction in growth rate of cucumber seedlings was due to the mannitol induced reduction in xylem pressure.

Mensah et al. (2009) discovered that an osmotic pressure value of $-0.5 \mathrm{MPa}$ of PEG reduced germination and radicle development of Nigerian sesame seeds with no shoot development. Similarly, Bahrami et al. (2012) showed that germination and seedling growth of sesame cultivars in Iran were reduced by PEG 6000 at 6 bar (-0.6 $\mathrm{MPa}$ ), whereas in the present study sesame plants showed such responses at comparatively lower water potential/ higher osmotic stress $(-1.00 \mathrm{MPa})$. Increase in turgor pressure in embryo cells by accumulating solutes within these cells overcomes the resistance of surrounding tissues of the seeds for radicle penetration (Welbaum et al., 1998). For instance, the accumulation of amino acids in embryos is evident during germination of lettuce seeds (Welbaum et al., 1998). A similar mechanism would have allowed Sri Lankan sesame seeds to germinate in a water limited environment by facilitating water uptake through osmosis. High tolerance of Belgian sesame genotypes exposed to osmotic stress severely affected germination and seedling growth at levels greater than $-1.00 \mathrm{MPa}$ (Boureima et al., 2011). The differences in tolerable limits in osmotic potential values could be due to the variability in tolerance in genotypes being tested in these experiments. As in this study, findings of both Boureima et al. (2011) and Bahrami et al. (2012) also indicated significant differences in response patterns among different sesame genotypes.

Drought causes severe damages to crops and livelihoods. Nearly half of the crop damages recorded from 1974 to 2008 in Sri Lanka was due to drought (Desinventer, 2012). Agricultural production was severely affected by drought during the Maha season in 2014 (World Food Programme, 2014). The entire dry zone is highly vulnerable to drought during Yala season (March to August) while the extreme regions in the North western and South eastern parts of the country are prone to severe drought conditions in Maha season (September to February) (Chithranayana \& Punyawardena, 2009). With increased events of drought, development of high yielding crops with drought tolerance has been suggested as one of the drought adaptation strategies (Eriyagama et al., 2010; World Food Programme, 2014). Therefore, it will be best to adapt for drought-tolerant crops in the drought-prone regions and sesame can be suggested as a suitable crop to cultivate in drought prone areas as it is mainly grown in the dry zone of Sri Lanka. There 
are sesame varieties that can tolerate drought stress as high as $-1.00 \mathrm{MPa}$ during germination and seedling growth. In response to simulated drought conditions in the field, Dissanayake et al. (2016), and Dissanayake and Ranwala (2017) reported that sesame expresses versatile morphological adaptations to survive drought. Less inhibitory influence by the salinity effect of $\mathrm{NaCl}$ indicates the salinity tolerance of Sri Lankan sesame varieties/cultivars in general. This ability to tolerate salinity stress can also be considered as an added advantage in selecting sesame as a potential crop for the future.

\section{CONCLUSION}

Different sesame varieties/cultivars responded differently to PEG, mannitol and $\mathrm{NaCl}$ treatments of simulated drought stress. Improved cultivars (Uma and Malee) were shown to be the most drought tolerant during germination while landraces (Idal and Pokuru) were the most tolerant to drought stress at the seedling stage. Wild sesame varieties were highly sensitive to water deficit during germination and seedling growth. These findings on varietal resilience to drought stress are of immense importance for farmers, plant breeders and scientific research. This work also reflects the pressing need to conserve the genetic diversity of the drought-tolerant sesame landraces and further crop improvements to strengthen their drought-tolerant traits.

\section{Acknowledgement}

Financial assistance provided by the National Science Foundation (NSF Grant No. RG/2011/AG/08) is acknowledged.

\section{REFERENCES}

Ali Q., Anwar F., Ashraf M., Saari N. \& Perveen R. (2013). Ameliorating effects of exogenously applied proline on seed composition, seed oil quality and oil antioxidant activity of Maize (Zea mays L.) under drought stress. International Journal of Molecular Sciences 14(1): 818-835. DOI: https://doi.org/10.3390/ijms14010818

Almansouri M., Kinet J.M. \& Lutts S. (2001). Effect of salt and osmotic stresses on germination in durum wheat (Triticum durum Desf.). Plant and Soil 231(2): 243-254. DOI: https://doi.org/10.1023/A:1010378409663

Alqudah A., Samarah N. \& Mullen R. (2011). Drought stress effect on crop pollination, seed set, yield and quality. Alternative Farming Systems, Biotechnology, Drought Stress and Ecological Fertilisation (eds E. Lichtfouse), pp.193-213. Springer, Dordrecht, Netherlands.
DOI: https://doi.org/10.1007/978-94-007-0186-1_6

Ashraf C. \& Abu-Shakra S. (1978). Wheat seed germination under low temperature and moisture stress. Agronomy Journal 70(1): 135-139.

DOI: https://doi.org/10.2134/agronj1978.00021962007000 010032x

Bahrami H., Razmjoo J. \& Jafari A.O. (2012). Effect of drought stress on germination and seedling growth of sesame cultivars (Sesamum indicum L.). International Journal of AgriScience 2(5): 423-428.

Bodner G., Nakhforoosh A. \& Kaul H.P. (2015). Management of crop water under drought: A review. Agronomy for Sustainable Development 35(2): 401-442. DOI: https://doi.org/10.1007/s13593-015-0283-4

Bor M., Seckin B., Ozgur R., Yilmaz O., Ozdemir F. \& Turkan I. (2009). Comparative effects of drought, salt, heavy metal and heat stresses on gamma-aminobutryric acid levels of sesame (Sesamum indicum L.). Acta Physiologiae Plantarum 31(3): 655-659.

DOI: https://doi.org/10.1007/s11738-008-0255-2

Boureima S., Eyletters M., Diouf M., Diop T.A. \& Damme P.V. (2011). Sensitivity of seed germination and seedling radicle growth to drought stress in sesame (Sesamum indicum L). Research Journal of Environmental Sciences 5(6): 557-564.

DOI: https://doi.org/10.3923/rjes.2011.557.564

Chithranayana R. \& Punyawardena B. (2009). Identification of drought prone agro-ecological regions in Sri Lanka. Journal of the National Science Foundation of Sri Lanka 36(2): 117-123.

DOI: https://doi.org/10.4038/jnsfsr.v36i2.143

De Costa W.A. (2004). Plant Water Relations: Principles and Applications. Faculty of Agriculture, University of Peradeniya, Sri Lanka.

De Costa W.A.J.M. (2010). Adaptation of agricultural crop production to climate change: A policy framework for Sri Lanka. Journal of the National Science Foundation of Sri Lanka 38(2): 79-89.

DOI: https://doi.org/10.4038/jnsfsr.v38i2.2032

Department of National Planning (2010). Sri Lanka the Emerging Wonder of Asia: The Development Policy Framework Government of Sri Lanka, pp. 15. Department of National Planning, Ministry of Finance and Planning, Colombo, Sri Lanka.

Desinventer (2012). Disaster Event and Impact Profile, Sri Lanka National Report on Disaster Risk, Poverty, and Human Development Relationship. Sri Lanka. Available at http://www.desinventar.lk/des_html/disaster_profile/ disaster profile.pdf, Accessed 10 June 2017.

Dissanayake I.A.J.K. \& Ranwala S.M.W. (2017). Sesame/thala (Sesamum indicum L.): a potential crop to meet challenges of climate change in Sri Lanka. In: Neela Haritha-Climate Change Magazine of Sri Lanka. The Climate Change Secretariat, Ministry of Mahaweli Development and Environment, Battharamulla, Sri Lanka.

Dissanayake I.A.J.K., Ranwala S.M.W. \& Perera S.S.N. (2017). Agronomic status of sesame/thala (Sesamum indicum L.) 
cultivations in dry regions of Sri Lanka. International Journal of Agronomy and Agricultural Research 11(1): 42-50.

DOI: https://doi.org/10.1155/2017/4767509

Dissanayake I.A.J.K., Ranwala S.M.W., Perera S.S.N., Nijamudeen M.S. \& Weerakoon W.M.W. (2016). Growth and yield performance of Sri Lankan grown sesame/thala (Sesamum indicum L.) and its wild relatives to water deficit conditions. Sri Lanka Journal of Environment Management and Planning 1: 1-13.

Elkheir H., Yunus M. \& Muslimin M. (2016). Duration of soil water content between field capacity and wilting point and its effect on growth of some aerobic rice cultivars (Oryza sativa L.). International Journal of Agriculture System 4(1): 36-45.

Eriyagama N., Smakhtin V., Chandrapala L. \& Fernando K. (2010). Impacts of Climate Change on Water Resources and Agriculture in Sri Lanka: a Review and Preliminary Vulnerability Mapping. International Water Management Institute, Colombo, Sri Lanka.

DOI: https://doi.org/10.5337/2010.211

Farooq M., Hussain M., Wahid A. \& Siddique K.H.M. (2012). Drought stress in plants: an overview. Plant Responses to Drought Stress from Morphological to Molecular Features (eds R. Aroca), pp.1-33. Springer, Heidelberg, Berlin, Germany.

DOI: https://doi.org/10.1007/978-3-642-32653-0

Farooq M., Wahid A., Kobayashi N., Fujita D. \& Basra S.M.A. (2009). Plant drought stress: effects, mechanisms and management. In: Sustainable Agriculture (eds E. Lichtfouse, M. Navarrete, P. Debaeke, S. Véronique \& C. Alberola), pp. 153-188. Springer, Dordrecht, Netherlands. DOI: https://doi.org/10.1007/978-90-481-2666-8_12

Harris K., Subudhi P., Borrell A., Jordan D., Rosenow D., Nguyen H., Klein P., Klein R. \& Mullet J. (2007). Sorghum stay-green QTL individually reduce post-flowering drought-induced leaf senescence. Journal of Experimental Botany 58(2): 327-338.

DOI: https://doi.org/10.1093/jxb/er1225

He G.H., Xu J.Y., Wang Y.X., Liu J.M., Li P.S., Chen M., Ma Y.Z. \& Xu Z.S. (2016). Drought-responsive WRKY transcription factor genes TaWRKY1 and TaWRKY33 from wheat confer drought and/or heat resistance in Arabidopsis. BMC Plant Biology 16(1): 116.

DOI: https://doi.org/10.1186/s12870-016-0806-4

Intergovernmental Panel on Climate Change (IPCC) (2014). Summary for policymakers. In: Climate Change 2014: Impacts, Adaptation, and Vulnerability. Part A: Global and Sectoral Aspects. Contribution of Working Group II to the Fifth Assessment Report of the Intergovernmental Panel on Climate Change (eds C.B. Field et al.), pp.1-32. Cambridge University Press, Cambridge, United Kingdom, and New York, USA.

James R.R., Buckner J.S. \& Freeman T.P. (2003). Cuticular lipids and silverleaf whitefly stage affect conidial germination of Beauveria bassiana and Paecilomyces fumosoroseus. Journal of Invertebrate Pathology 84(2): $67-74$.
DOI: https://doi.org/10.1016/j.jip.2003.08.006

Lambers H., Chapin III F.S. \& Pons T.L. (2008). Plant Physiological Ecology, $2^{\text {nd }}$ edition. Springer-Verlag, New York, USA.

DOI: https://doi.org/10.1007/978-0-387-78341-3

Luan Z., Xiao M., Zhou D., Zhang H., Tian Y., Wu Y., Guan B. \& Song Y. (2014). Effects of salinity, temperature, and polyethylene glycol on the seed germination of sunflower (Helianthus annuus L.). The Scientific World Journal 2014: 1-9.

DOI: https://doi.org/10.1155/2014/170418

McNair J.N., Sunkara A. \& Frobish D. (2012). How to analyse seed germination data using statistical time-to-event analysis: non-parametric and semi-parametric methods. Seed Science Research 22(2): 77-95.

DOI: https://doi.org/10.1017/S0960258511000547

Mensah J., Obadoni B., Eruotor P. \& Onome-Irieguna F. (2009). Simulated flooding and drought effects on germination, growth, and yield parameters of Sesame (Sesamum indicum L.). African Journal of Biotechnology 5(13): 1249-1253.

Nath R., Chakraborty P. \& Chakraborty A. (2001). Effect of climatic variation on yield of sesame (Sesamum indicum L.) at different dates of sowing. Journal of Agronomy and Crop Science 186(2): 97-102.

DOI: https://doi.org/10.1046/j.1439-037X.2001.00456.x

Odabas M.S., Leelaruban N., Simsek H. \& Padmanabhan G. (2014). Quantifying impact of droughts on barley yield in North Dakota, USA using multiple linear regression and artificial neural network. Neural Network World 24(4): 343-355.

DOI: https://doi.org/10.14311/NNW.2014.24.020

Olowe V., Adeyemo Y. \& Adeniregun O. (2009). Sesame: the underexploited organic oilseed crop. Journal of Science and Sustainable Development 2(1): 29-32.

DOI: https://doi.org/10.4314/jssd.v2i1.67554

Patel T.K. \& Williamson J.D. (2016). Mannitol in plants, fungi, and plant-fungal interactions. Trends in Plant Science 21(6): 486-497.

DOI: https://doi.org/10.1016/j.tplants.2016.01.006

Ramírez R., Gutiérrez D., Villafañe R. \& Lizaso J.I. (2007). Salt tolerance of sesame genotypes at germination, vegetative, and maturity stages. Communications in Soil Science and Plant Analysis 36(17-18): 2405-2419.

DOI: https://doi.org/10.1080/00103620500253324

Ramya P., Singh G.P., Jain N., Singh P.K., Pandey M.K., Sharma K., Kumar A., Harikrishna \& Prabhu K.V. (2016). Effect of recurrent selection on drought tolerance and related morphophysiological traits in bread wheat. Plos One 11(6): e0156869.

DOI: https://doi.org/10.1371/journal.pone.0156869

Richards R. (2005). Effects of Ionic and Osmotic Stress on Lettuce, Radish and Crested Wheatgrass. Utah State University, USA.

Sanders G.J. \& Arndt S.K. (2012). Osmotic adjustment under drought conditions. Plant Responses to Drought Stress from Morphological to Molecular Features (eds R. Aroca), pp.199-230. Springer, Heidelberg, Berlin, Germany. 
DOI: https://doi.org/10.1007/978-3-642-32653-0

Stahlberg R. \& Cosgrove D.J. (1997). Mannitol inhibits growth of intact cucumber but not pea seedlings by mechanically collapsing the root pressure. Plant, Cell and Environment 20(9): 1135-1144.

DOI: https://doi.org/10.1046/j.1365-3040.1997.d01-141.x

Thattil R.O., Samitha S., Gunaratne L.P., Dematawewa C.M.B.

\& Chandrasiri C.W.J. (1999). Handbook on Design and Analysis of Experiments. Postgraduate Institute of Agriculture, University of Peradeniya, Peradeniya, Sri Lanka.

Verslues P.E., Agarwal M., Katiyar-Agarwal S., Zhu J. \& Zhu J.K. (2006). Methods and concepts in quantifying resistance to drought, salt and freezing, abiotic stresses that affect plant water status. The Plant Journal 45(4): 523-539. DOI: https://doi.org/10.1111/j.1365-313X.2005.02593.x

Weeraratna C.S. \& Weerasinghe P.A. (2009). Agriculture of Sri Lanka. Sridevi Printers, Dehiwala, Sri Lanka.

Welbaum G.E., Bradford K.J., Yim K.O., Booth D.T. \& Oluoch M.O. (1998). Biophysical, physiological and biochemical processes regulating seed germination. Seed Science Research 8(2): 161-172.

DOI: https://doi.org/10.1017/S0960258500004074

World Food Programme (2014). Sri Lanka - Rapid Drought Impact Assessment: Food Security and Livelihoods Affected by Erratic Weather, April 2014. Sri Lanka: World Food Programme. Available at http://www.wfp.org/content/ sri-lanka-rapid-drought-impact-assessment. Accessed April 2014 